\title{
The Occupational Career Paths of Australian Tradesmen *
}

\author{
Elizabeth Webster and Kelly Jarvis \\ Melbourne Institute of Applied Economic and Social Research \\ The University of Melbourne
}

Melbourne Institute Working Paper No. 14/03

ISSN 1328-4991 (Print)

ISSN 1447-5863 (Online)

ISBN 0734031270

May 2003

* We gratefully acknowledge the financial support from the National Council for Vocational Education Research and would also like to thank Lara Hammond and Penny Hope for assistance with the administering the survey and Rosy Qin for assistance with drawing. In addition, we thank Jennifer Gibb, John Freebairn and an anonymous referee for useful comments. The responsibility for content and any remaining errors rest with the authors.

Melbourne Institute of Applied Economic and Social Research

The University of Melbourne

Victoria 3010 Australia

Telephone (03) 83445330

Fax (03) 83445630

Email melb-inst@unimelb.edu.au

WWW Address http://www.melbourneinstitute.com 


\begin{abstract}
This paper asks whether the high rates of both unqualified tradespeople and attrition of qualified tradespeople from trade work necessarily represent inefficiencies in the skill acquisition process for the skilled trades. We argue that it is possible that there are three streams of trade workers $-\mathrm{a}$ lower stream, which requires the least academic and vocational skills and embodies short and flat experience profiles; a higher stream which demands more academic and vocational expertise and steeper experience profiles and a third, more traditional trade stream which lies in-between. This view is supported by persistent patterns in tradesmen's career paths. Polarisation into the highest and lowest streams appears to be increasing over time. If valid, these findings suggest that there should be several tiers of training for the trade labour markets.
\end{abstract}




\section{INTRODUCTION}

The skills of strategic people within an organisation are increasingly being recognised as the core capability that determines enterprise success and a nation's comparative advantage. By extension, the efficacy of the skill acquisition pathways for these workers should fall under scrutiny. Job skills are primarily acquired though three mediums - formal training, education and accumulated career experiences. This paper looks at the difficult and imprecise notion of 'the best skill acquisition pathway' through an interpretation of data on tradesmen's career paths and training histories. We use factors associated with tradesmen who stay or gain seniority within trade related career paths, compared with those who leave the trade or lapse into lesser skilled trade work, as indicators of preferred pathways for different streams of worker.

The central focus throughout our study is the metal, building, automotive and electrical trades which comprise over two thirds of the traditional trades. As almost all of these trade workers are men, the data relate exclusively to tradesmen. The following section discusses how one can approach the problem of efficient pathways; section three describes the survey of 1125 men which was undertaken for this survey, section four analyses the different career paths. Finally, section five concludes

\section{HOW TO DEFINE THE EFFICIENT SKILL ACQUISITION PATH}

Work skills are acquired through four main mediums. First, the education sector which instils individuals with the basic communication and analytic skills as well as a broad awareness of the world, secondly, vocational training which equips the person with the foundation technical abilities necessary for the respective vocation, thirdly, short formal training programs which provide ad hoc supplementation to the foundation skills, and finally, work experience, or learning-by-doing, which is the primary vehicle for the acquisition for tacit work skills. Most 
skilled occupations require the first and last forms of skill acquisition, but increasingly, short ad hoc formal training programs are being administered to employees through their places of employment. Some professions, and most technical and trade occupations require, either in principle or by regulation, vocational training as well.

A theoretical 'best' skill acquisition path for trade work could be said to follow the sequence set out in Figure 1 below. Education is followed by formal vocational education (often, but not necessarily, an apprenticeship) and subsequently experience as a skilled worker (journeyman). The pathway through to a senior journeyman, supervisor, technician and manager is propelled by skills acquired through this work experience, and may be supplemented with short ad hoc training courses, further education and supplementary vocational training. A priori, we would expect that as the skills required for an occupation become more regular, systematic and less tacit, it is economical to rely more on formally encoded training and education regimes and less on work experience mediums. What has previously been acquired through 'sitting-by-nellie', is now documented and condensed into a program of instruction.

For sometime, there has been considerable evidence of two major forms of divergence from this 'best' skill pathway in the trade labour markets. First, large inflows into the trade consist of men who have not completed formal vocational training (point A in Figure 1). While this relative inflow has fallen in the last 25 years, it remains high and the most recent data (1996) estimate that 2.5 in 10 metal, vehicle and electrical tradesmen and 3 in 10 building tradesmen did not have formal vocational qualifications.

Secondly, there are large outflows of tradesmen, both qualified and unqualified, to unrelated jobs, before normal retirement age (point B in Figure 1). In 1996, 18 per cent of metal, vehicle and electrically qualified tradesmen and 14 per cent of qualified building tradesmen were 
working in these less skilled jobs. A further 8 to 13 per cent were working in clerical and sales jobs where the relevance of trade skills is unclear (Webster et al. 2001, Ch. 2). The outflow of unqualified but experienced and skilled tradesmen has largely been undocumented. While zero skill separation is unlikely to be optimal, most trade occupations have historically enjoyed the dubious position of having the highest rates of mismatch between qualifications and jobs (see Thomas 1988b and Thomas 1988a).

For some time, excessive leakage and informality within the trades labour markets has underpinned the view that trade workers were not acquiring their skills through the most efficient routes (Greenhalgh and Stewart 1987, Nickell 1982 and Webster et al. 2001). It has been thought that blockages in the apprenticeship system ${ }^{1}$, and sub-optimal training rates has forced employers to upgrade unqualified workers and rigid wages relativities has lead to high attrition of skilled workers before and during middle age.

On this rationale, a (small) number of government and non-government surveys have been undertaken in Australia to enquire why employers employ unqualified tradespeople and why qualified tradespeople leave their trade of training prematurely. Somewhat surprisingly, these have revealed that difficulties recruiting formally trained workers are not a major reason why employers upgrade. Employers experiencing skill shortages in the trade and technical area are no more likely to upgrade, that is, promote unqualified workers to skilled jobs, than other employers (Webster et al, 2001, Ch. 2). Surveys of attrition, on the other hand, have found that many qualified tradespeople are leaving to get more financially rewarding work or to seek variety and challenge in their work (Webster et al 2001 Ch. 6). However, apart from those who move into managerial or administrative positions, qualified tradespeople who leave their trade are not

\footnotetext{
${ }^{1}$ The number of training places is rarely responsive to either demand by individuals or demand for skilled tradespeople. As apprenticeship places are embodied in an employment offer, it is highly affected by the state of the economy (see Webster 1983).
} 
earning significantly more than those who remain. It is not clear either that this loss of tradespeople from their trade is inefficient, since the current enterprise bargaining system, as well as its award based predecessor, do, and did, not exclude or discourage employers from offering higher wages to retain valued workers. Instead, it appears that employers do not value the skills of these dissatisfied workers highly enough to try to retain them by offering higher wages.

The suggestion that employers upgrade unqualified workers because of market failure within the training system does not appear compatible with the data. An alternative perspective eschews this notion of an a priori optimal skill acquisition path in favour of interpreting what is actually happening as indicators of preferred or 'best' pathways. Under this view, actual skill acquisition paths tend towards the best paths, subject to institutional and cultural boundaries. If multiple forms of skill acquisition for the same occupation exist therefore, the one that equips people more efficiently (more thoroughly and or at lower cost) will, over time, come to be preferred by workers and employers. ${ }^{2}$ Accordingly, people trained through the most efficient pathway will increasingly tend to dominate the occupation, ceteris paribus. However, the presence of uncertainty and institutional inflexibility implies that the most efficient mode may take considerable time to be little known or discovered because of the slow rate of diffusion of knowledge and understanding in the community.

Notwithstanding the impediments to the development of skill pathways, we explore in this paper the premise that preferred skill pathways will, if it is better than the next alternative by a significant margin, tend to dominate a career path. Accordingly, evidence of several different

\footnotetext{
${ }^{2}$ Accordingly, if indenture terms are permitted by regulation to be 3 to 4 years instead of a minimum of 4 , and we find subsequently that most apprenticeships reduce to 3 years, then we can conclude that 3 years is a better arrangement from the combined individual's and employer's point of view.
} 
major skill acquisition paths may indicate multiple tiers or streams within occupations, rather than inefficient diversions from the one 'best' pathway.

Existing studies of skill acquisition pathways for tradespeople are scarce, but studies of career progression more generally, reveal a number of consistent findings or stylised facts. The first is that a person's first job after leaving full time education and formal qualifications are important predictors of later career advancement (Nickell 1982, VandenHeuvel and Wooden 1996, Webster 2001). However, these studies do not allow us to assess whether first jobs and the formal qualifications affected career paths or whether these and career paths were determined by independent personal characteristics. Secondly, undertaking formal vocational training does appear to enhance careers and/ or wages (Greenhalgh et al. 2000, Booth 1991). Thirdly, the personal characteristics of the employees, such as age, career aspirations, attitudes to training and formal qualifications affect how willing employers are to offer a person firm based training (Greenhalgh and Mavrotas 1996, Greenhalgh and Mavrotas 1994, Green 1993). Young workers, those positively disposed toward training and those with higher qualifications and/or higher status jobs are more likely to receive training, ceteris paribus. A consistent theme throughout all these studies is the importance of workers' personal characteristics and their existing qualifications.

The following section examines data from a survey of 1125 men who had spent some time in their working careers in the light of the second perspective of skill acquisition pathways. 
Figure 1: Stylised versions of 'best' formal and informal skill acquisition pathway for trade workers

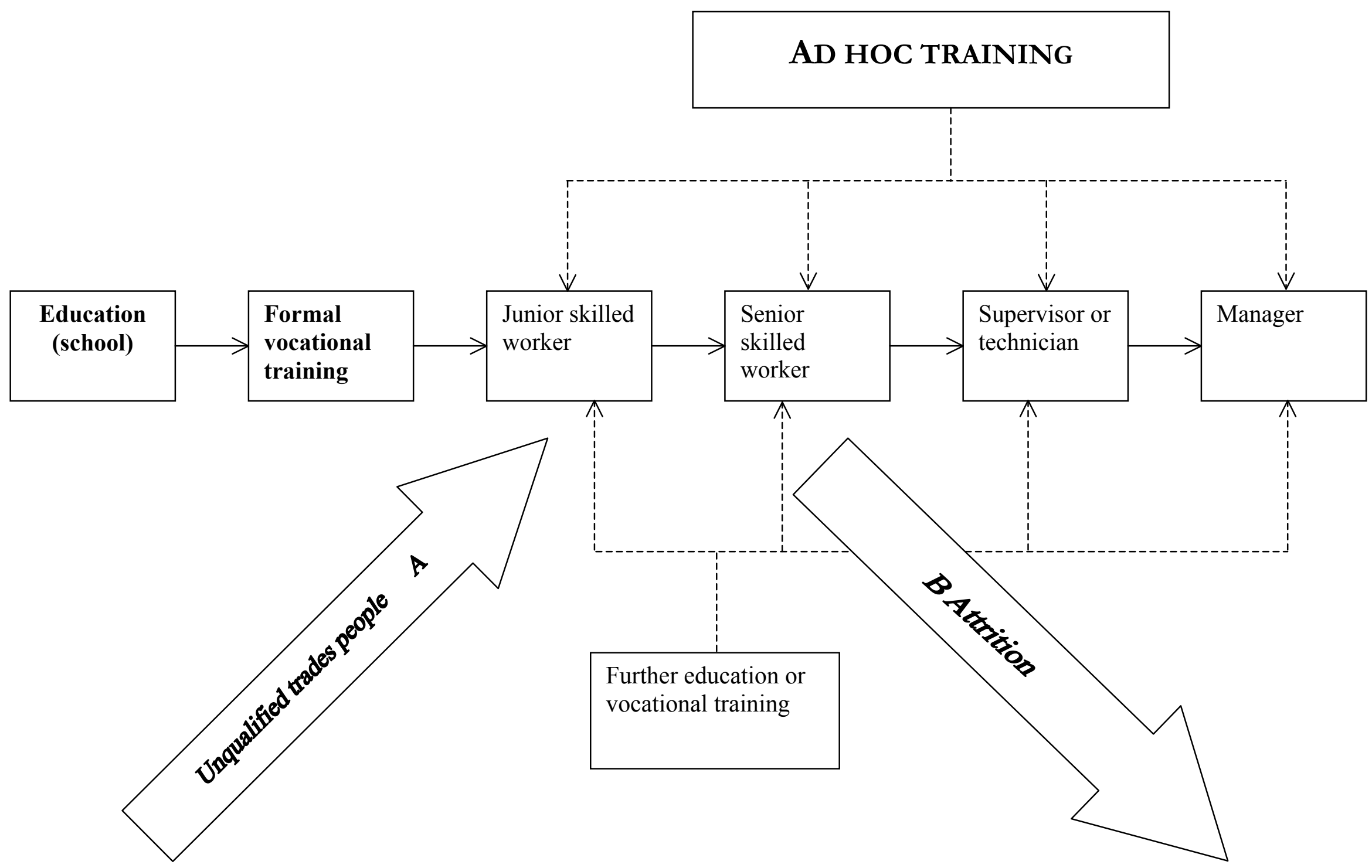




\section{SURVEY OF TRADESMEN}

Longitudinal data on workers' skill acquisition pathways rare in Australia, ${ }^{3}$ and since most surveys cover all occupations the numbers of workers from the trade labour markets are generally too small for much analysis. Because of this we undertook our own primary data collection and surveyed 1125 men who were working or had previously worked in a trade job, via a postal survey over the period June 2000 to October 2001. Details of this survey are described in Appendix A.

Respondents were asked to provide information on their first job and subsequent jobs at 18, 25, 30, 35 and 40 years of age. In all, 611 men had surpassed the age of 40 and provided valid responses to these questions. To reduce the number of data categories, we grouped occupations into five occupation categories: Unskilled, Clerical and Sales, Trade, Higher Skilled (includes technicians, professionals, supervisors and managers) and Not Working. This gives us 3125 possible career paths to the age of 40 which are too many to describe, and arguably too many to analyse, with any level of confidence. Consequently, we have grouped career paths into six stylised career paths using cluster analysis and these are summarised in Table 1 and represented graphically in Figures 2 to 7. Cluster analysis groups data by minimising the variation inside the clusters and maximising the variation between the clusters. However, the choice of what variable to use and the weight given to each variable is a discretionary choice and is based upon matters we believe define homogeneity. For the career paths clusters, the variables were weighted toward the first job so the clusters generally start with all men working at the same skill level.

Men's occupations are self-enumerated and the data is not strictly comparable with interview based surveys. Extensive experience by the Melbourne Institute of Applied Economic and Social Research has found that in self-enumerated surveys, people tend to over estimate the level of skill of

\footnotetext{
${ }^{3}$ While there are several work and training history survey, the Australian Council for Educational Research's YIT and LSAY surveys are probably the only panel surveys of any length.
} 
their job compared with the Australian Bureau of Statistics (ABS) Labour Force Survey.

Accordingly, our survey method leads to an overstatement of the numbers in managerial,

professional and associate professional positions and understate the numbers in unskilled work

compared to more careful ABS interview based methods. We have not sought to adjust the data for these differences in definition and these discrepancies should be born in mind when interpreting the evidence.

Table 1: Frequencies of Career Path Clusters

\begin{tabular}{llcc}
\hline Cluster & Name & Size & Per cent \\
\hline 1 & Remain higher & 78 & 12.8 \\
2 & Clerical/sales to mixed & 82 & 13.4 \\
3 & Trade to lower & 63 & 10.3 \\
4 & Trade to higher & 126 & 20.6 \\
5 & Remain trade & 129 & 21.1 \\
6 & Unskilled to mixed & 133 & 21.8 \\
Total & & 611 & 100.0 \\
\hline
\end{tabular}

Cluster One ('Remain higher') describes men who began in higher skilled positions, mainly technical or professional jobs, and for the most part, remain in them until the age of 40, with only 8 per cent moving down into trade jobs. Cluster Two ('Clerical/sales to mixed ') describes workers who began work in clerical, sales or personal service work. By the age of 40, almost 50 per cent had progressed to higher skilled positions, 18 per cent remained in clerical sales or service work, 18 per cent had moved into a trade and 12 per cent took unskilled work.

Cluster three ('Trade to lower'), describes men who began in a trade but predominantly moved into lower skilled or clerical and sales jobs by the age of 40 years. Only 6 per cent remained in trade until the age of 40. All men in cluster four ('Trade to higher'), began in trade. However, there was a strong and steady movement over time from trade work into higher skilled jobs such that by the age 35 years, 97 per cent of cluster four was in higher skilled occupations. Cluster Five ('Remain trade') describes men who remain in trades for their entire career to the age of 40. 
Cluster six ('Unskilled to mixed'), describes men who made the transition from unskilled work into trade or higher skilled occupations. All of the men grouped into cluster six began work in an unskilled occupation, however by 25 years of age, 32 per cent had moved in trade and 14 per cent had moved into higher skilled positions. After the age of 25 , the number of people in trade remained relatively stable, but there continued to be a minor transfer from unskilled occupations into higher skilled areas. By the age of 40, 28 per cent remained in unskilled, 29 per cent were in trades and 35 per cent were in higher skilled positions.

Figure 2: Cluster One, Remain Higher

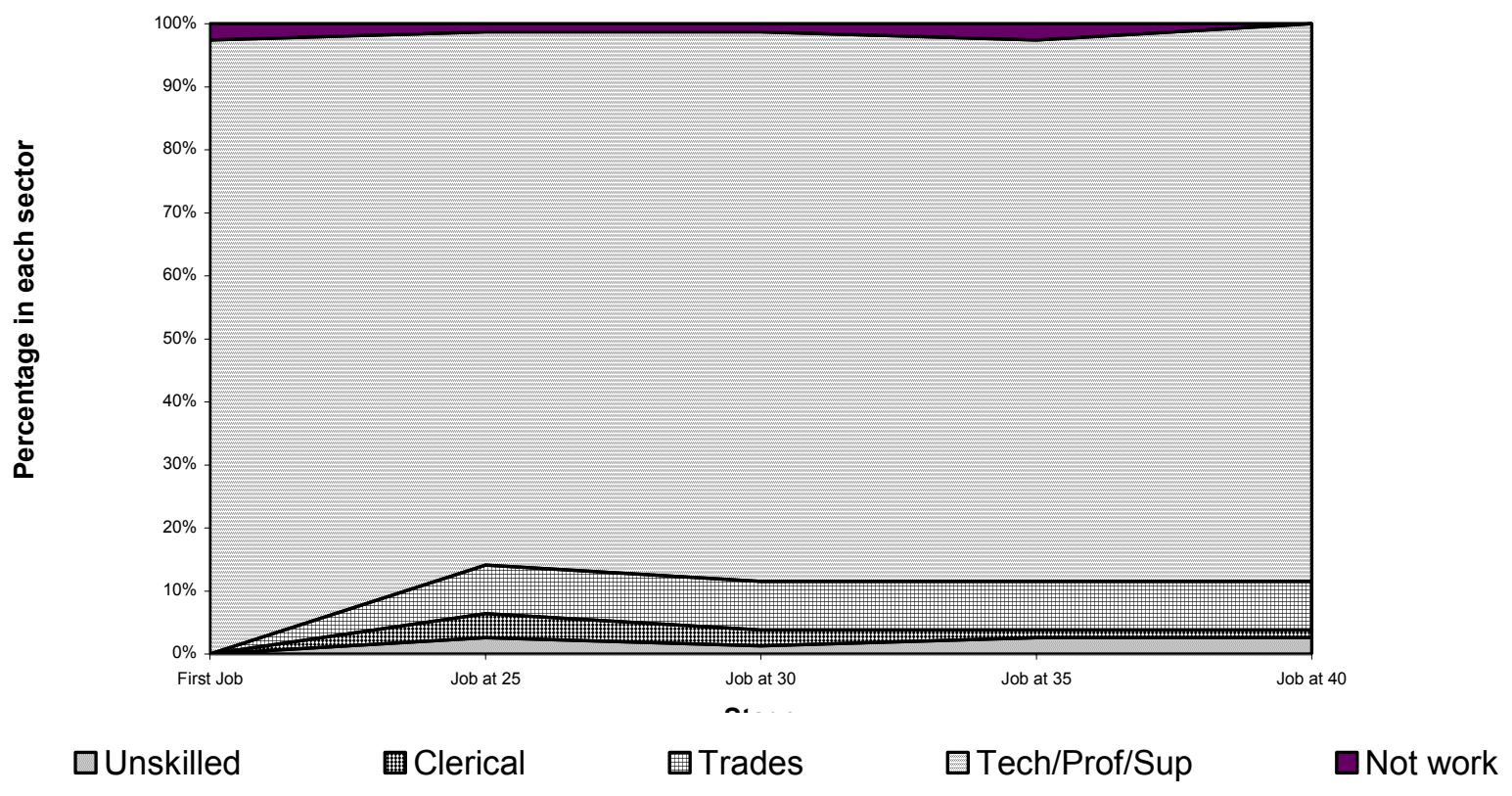


Figure 3: Cluster Two, Clerical/Sales to Mixed

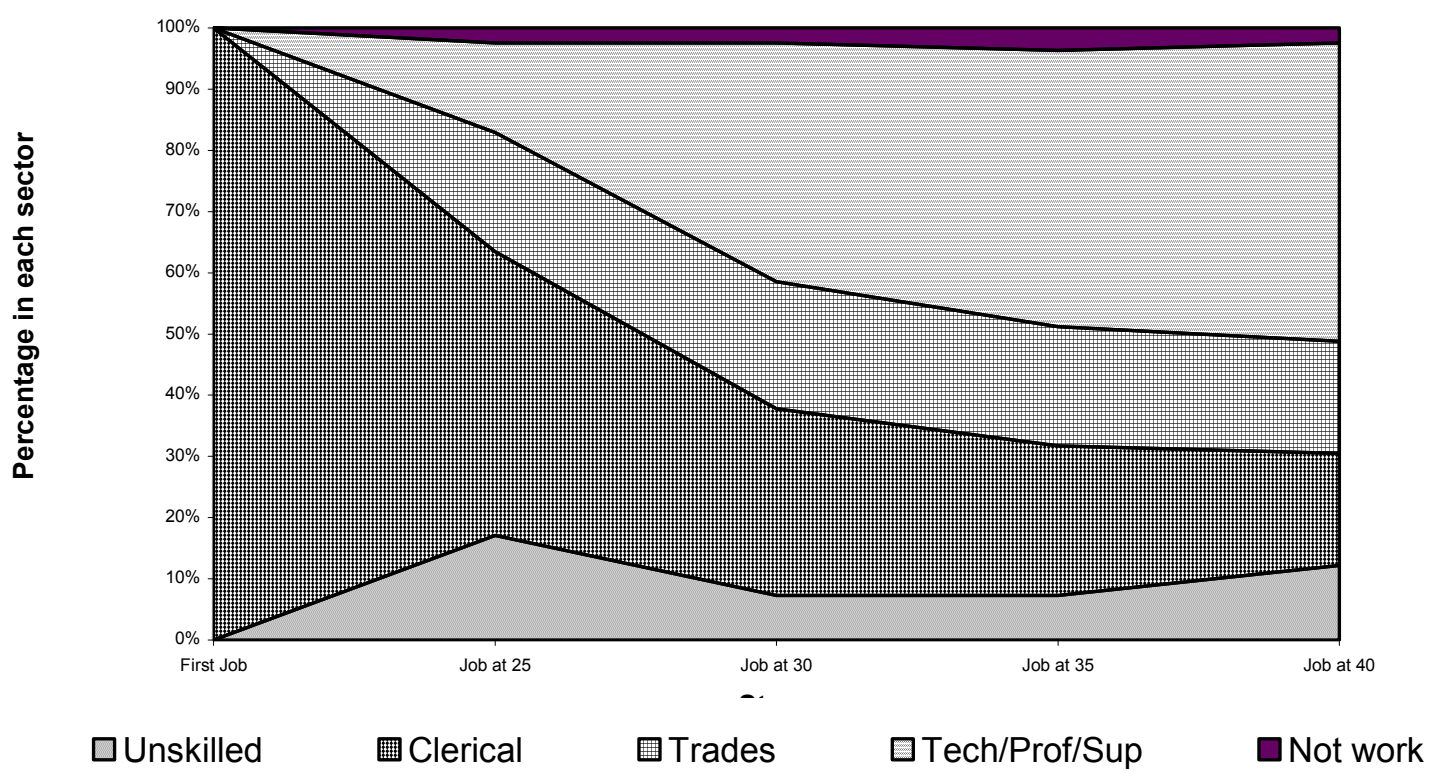

Figure 4: Cluster Three, Trade to Lower

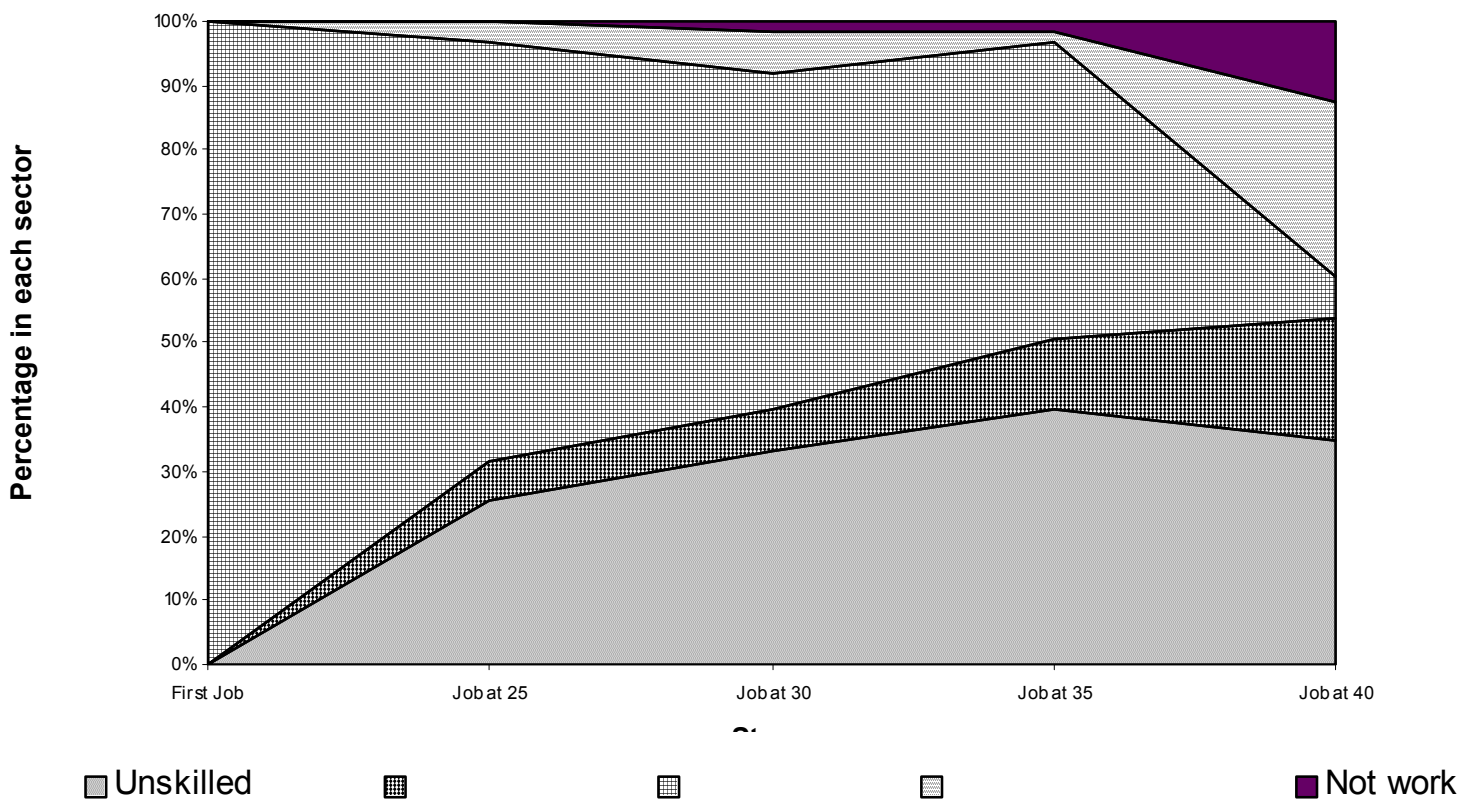


Figure 5: Cluster Four, Trade to Higher

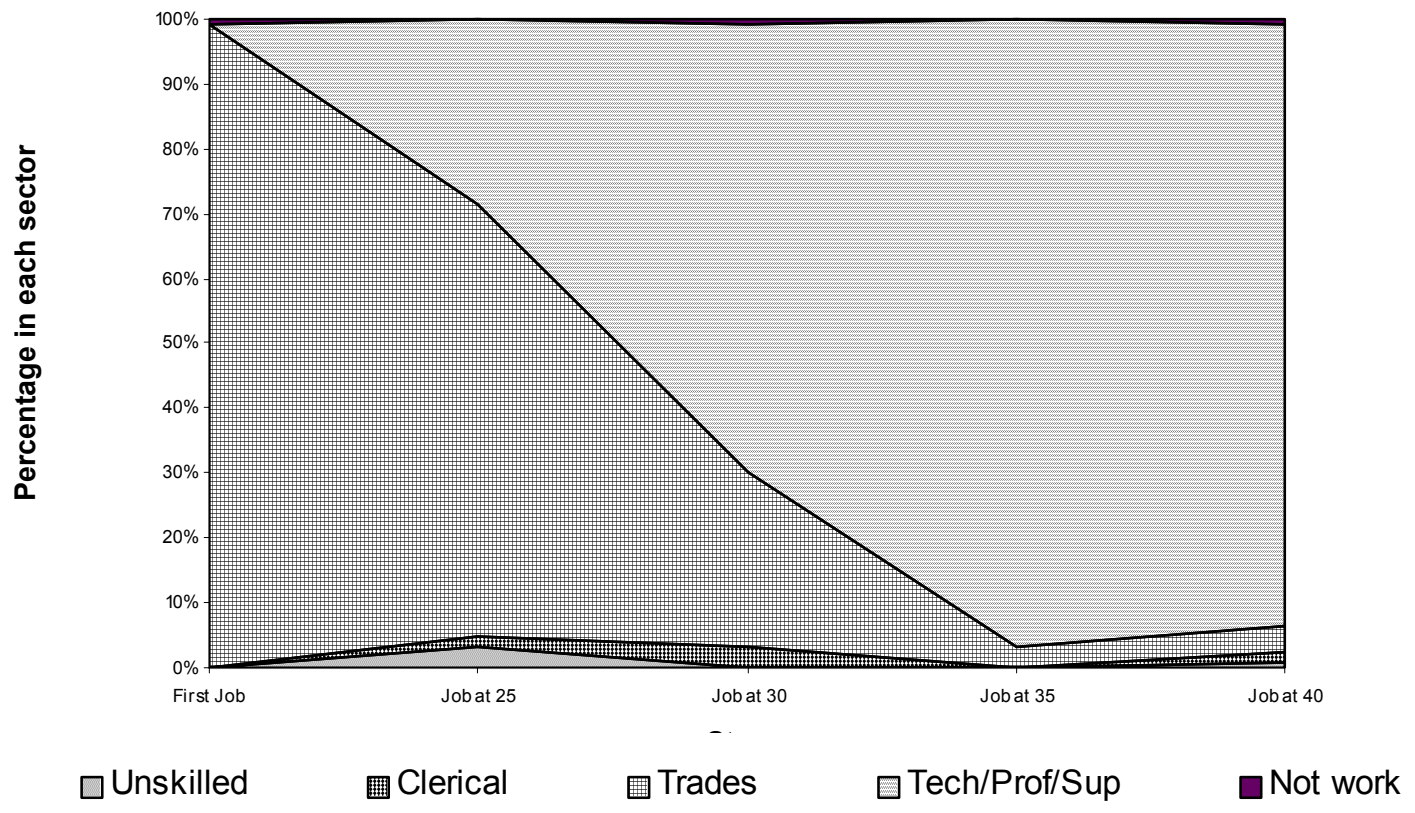

Figure 6: Cluster Five, Remain in Trade

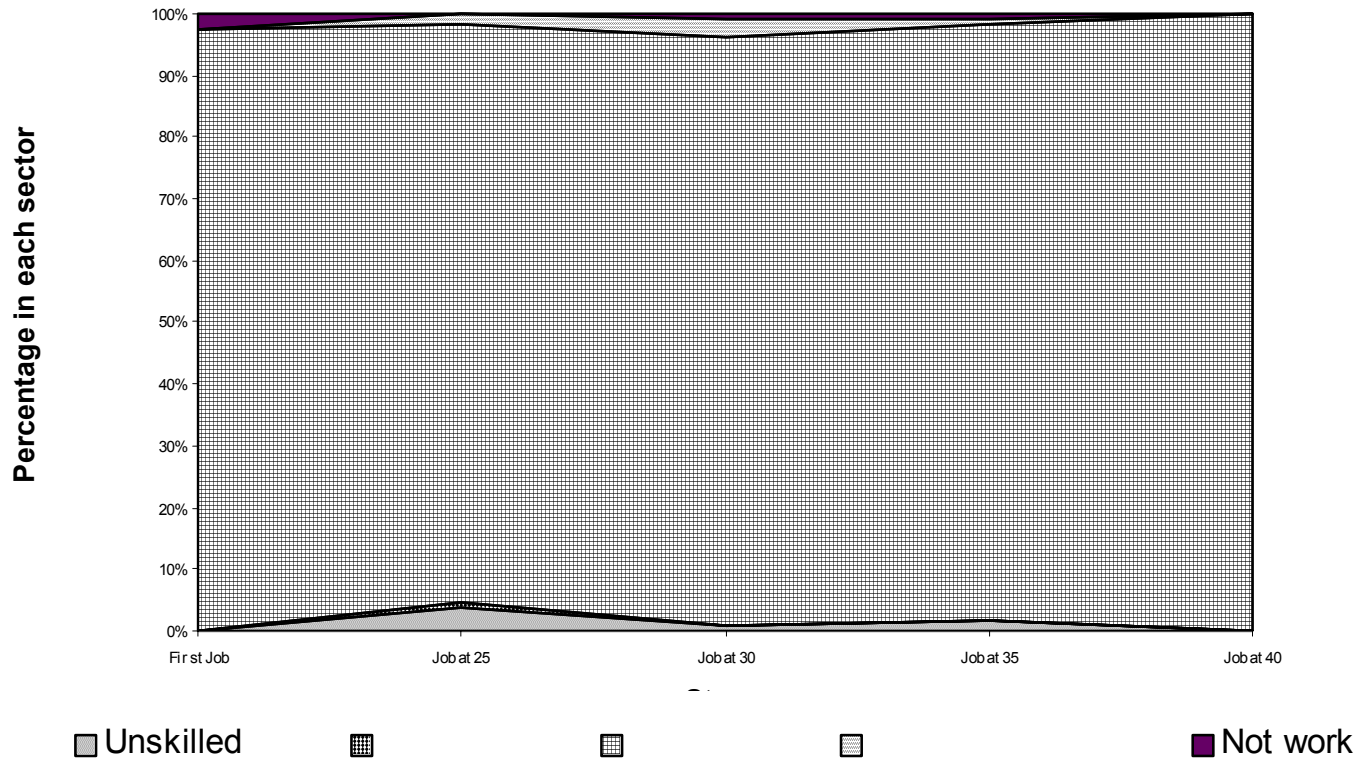


Figure 7 : Cluster six, unskilled to mixed

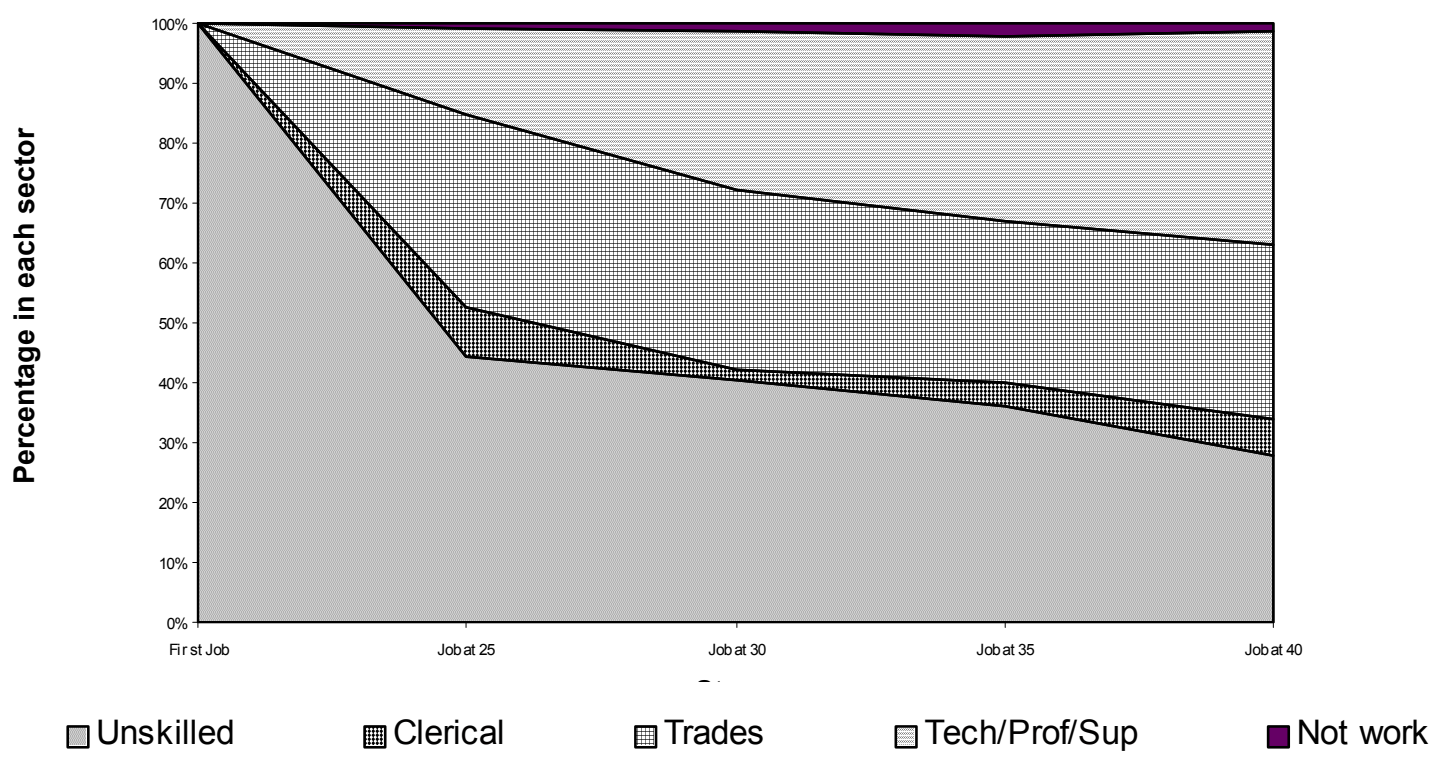

To summarise, most of the men from our sample followed progressive career paths from lesser skilled occupations to more skilled ones. The main exception is the group of men, over 15 per cent of the sample, who began in the trade but later detoured into less clearly related work such as lesser skilled jobs or non-trade clerical and sales jobs. About half of the men in the trade labour market began their working careers in the trade, and of these, four in five either remained in trade work or progressed into higher skilled jobs. Men who began in a higher or trade job and remained there are arguably following career paths which recognise accumulated skills. The 20 per cent who graduated from unskilled work to trade work by the age of 40 are also following a positive career progression.

\section{FACTORS ASSOCIATED WITH DIFFERENT CAREER PATTERNS}

To investigate the factors associated with workers who pursued different skill acquisition routes through differing career paths, regression analysis was undertaken on the six stylised career paths. Table 2, which is based on the multinomial logit regression results in Appendix B, calculates the 
effects of varying significant background characteristics on the probability that a given man will follow each path.

Our estimates found that whether a man was born in Australia, a main English-speaking country or a non-English-speaking background country, and in the case of the foreign born, the age at migration, had no effect on the cluster or career path that they belonged to. Similarly, parents' educational backgrounds had no effect. Birth cohort, own level of schooling and post-school qualifications however, all provided some statistically significant association.

Table 2: Marginal effects on the probability of workers following different career paths (to the age of 40)

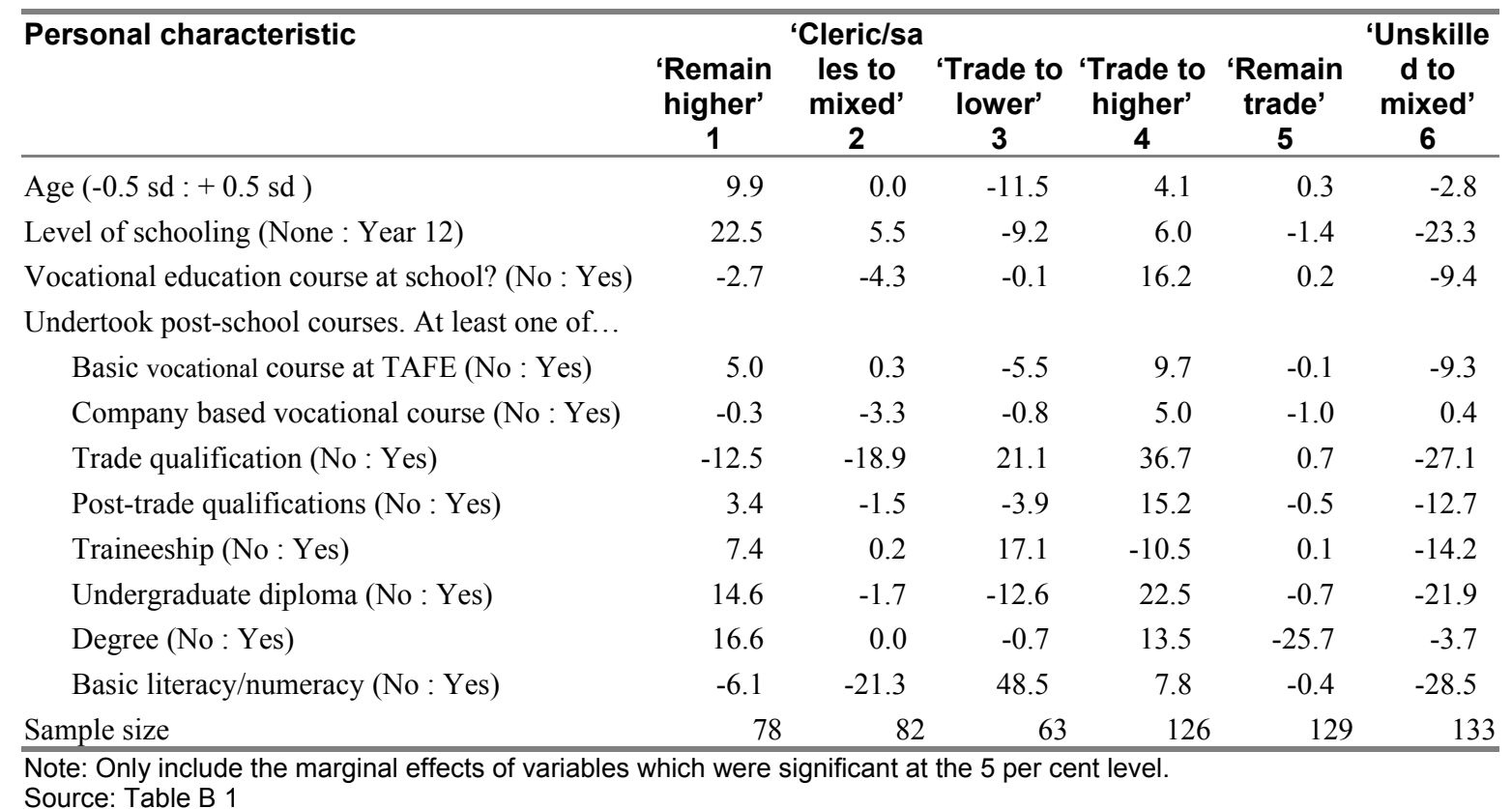

Table 2 indicates the changes to the probability of belonging to each career path arising from a variation in the significant background characteristics. For example, if we raised the notional man's age from 0.5 standard deviations below the mean to 0.5 standard deviations above the mean, then the probability of him belonging to cluster 1 'Remain higher' is raised by 9.9 percentage points and the probability of belonging to the other clusters is accordingly reduced. Each row in Table 2 should thus sum to zero. 
Results presented in Table 2 show that more recent cohorts of men are more likely to be mobile over their careers by moving downward from trade positions to lesser skilled manual, clerical and sales jobs (cluster 3) or by moving upward from unskilled and clerical/sales work to trade work (cluster 6). By contrast, older cohorts of men were slightly more likely to enter a supervisory, technical or professional jobs and remain there (cluster 1).

Level of schooling had a major impact on how men began their careers. Men who had completed year 12 (or equivalent) were most likely to begin their careers in a technical, supervisory, professional or managerial job (cluster 1) and least likely to start in an unskilled job. Higher levels of education were also associated with starting work in a clerical/sales job (cluster 2). While the remaining men began work in the skilled trades, the higher was the level of schooling, the more likely was the man to progress to a more skilled job later in their careers, all other things considered (cluster 4).

Whether or not the man undertook a vocational or technical course while at school appeared to predispose men toward first, starting out work in a trade job (clusters 3 , 4, and 5) and secondly progressing into higher level skilled work (cluster 4). Men who did not undertake these courses were also more likely to begin their careers in unskilled jobs and only later move into trade or technical work (cluster 6).

However of all the factors considered, men's post-school training and education histories had the most profound effect on which career path they followed. Consider first men who started their careers in the skilled trades. Compared to men who remained in the trade or later took unskilled or clerical work, men who moved into higher jobs were more likely to have undertaken one or more courses of post school training and education other than a traineeship and basic numeracy and literacy course (cluster 4). Compared to men who remained in the trade, men who left trade work 
for unskilled or clerical work were more likely to have completed a trade qualification, a traineeship or have undertaken basic numeracy and literacy courses (cluster 3).

Few men who moved from unskilled work to trade work or higher had any post-school qualifications (cluster 6). Men who began their careers in higher skilled sector technical, professional, supervisory and managerial jobs had the most post-school qualifications on all accounts except for post-trade qualifications and basic numeracy and literacy courses (cluster 1).

To summarise, undertaking vocational training while at school and the level of schooling completed had the most important influence on the first job men took after leaving full-time education ceteris paribus. More schooling was associated with a greater chance that they would enter through a higher skilled technical, supervisory or professional job. Undertaking vocational training at school increased the chances that the man would take a trade (apprentice) position. Early school leavers who did not take vocational courses at school had the greatest chance of beginning their working careers in unskilled work. Once in a trade job, all forms of formal post-school training, except for traineeships and basic numeracy and literacy courses, were associated with progressing along the career path toward higher skilled technical, professional, supervisory and managerial positions.

Additionally, there is some evidence that upward and downward mobility from unskilled work to higher skilled work had increased over time. Tradesmen with limited schooling and few vocational and post-school training courses had the greatest chance of leaving trade work for less skilled work before the age of 40 .

These results do not necessarily imply that participation in these training and education courses have contributed towards career path development, or indeed that participation in a traineeship or basic numeracy and literacy course has held men back. The analysis does not, and unfortunately cannot, control for personal characteristics such as ability, determination, focus and reliability. If 
these positive personal characteristics are a major factor in influencing a man's training and educational decisions - and it is hard to believe that it has no influence - then we will observe a positive and significant relationship between education and training and career progression for reasons unrelated to the value of that education and training. While there are grounds for arguing that men who acquire skills through more formal training programs than others are more successful in their careers, the question we cannot answer here is the extent to which the formal education and training programs by themselves assist career progression because the recipients receive skills through a more efficient skill acquisition path.

To test further for the trend over time on tradesmen's career progression, we examined the factors associated with men's job changes. Jobs were classified into 3 categories (in rising order of skill), first, unskilled and clerical and sales, secondly, trade and thirdly, higher skilled. Changes to or from non-working states were excluded from the data. Reported jobs at 25, 30, 35 and 40 years of age were classified according to whether they involved no change or a change up or down in the skill ladder. This observed career progression (or lack of ) was regressed against a set of independent variables which included the personal characteristics and whether they had undertaken a post-school qualification prior to the job change. A dummy variable was included to test for whether the award restructuring process affected career progression post-1988.

We found that level of completed school education, parents' level of education, and whether the man had undertaken a vocational course during his schooling had no effects on the probabilities of career progression. However, the remaining variables including, age at migration (zero if Australian born), whether born in Australia, whether and what sort of post-school training they had undertaken prior to the job changes, were statistically significant. Results from a multinomial logit regression are presented in Table B 2, and the marginal effects of each significant variable on the probability of belonging to each outcome are given below in Table 3 . 
While Australian born men were less likely to move up than immigrants, the older the man was on arrival, the less likely they were to move up and the more likely they were to move down over their careers (possibly because of the negative effects of possessing foreign qualifications). Existing post-school qualifications had a significantly smaller effect on probability of changing jobs to a higher or lower skill level. Having previously participated in a short TAFE courses was positively, but marginally, associated with changing up the skill ladder. Company based courses were associated with a smaller probability of changing down, but trade qualifications had no significant association. Having undertaken an undergraduate diploma or post trade qualification was associated with a reduced chance of changing down but having acquired a degree had mixed effects.

A considerable portion of the career progression was picked up by the trend variable (year of job change) and not the individual characteristics. This is consistent with population census information since 1948 which shows that there has been a trend growth in the employment of high and low skilled occupational at the expense of trade occupations since 1948 in Australia (Webster 1999). According to our estimations, a man was 7.1 per cent more likely to change up and 10.4 more likely to change down in 1994 compared with 1970. 
Table 3: Marginal effects on the probability of workers changing jobs at each 5-year interval (to the age of 40$)^{(a)}$

\begin{tabular}{|c|c|c|c|}
\hline \multirow[b]{2}{*}{ Personal characteristic ${ }^{(b)}$} & \multicolumn{3}{|c|}{ Remain } \\
\hline & $\begin{array}{c}\text { Change } \\
\text { down }\end{array}$ & $\begin{array}{c}\text { the } \\
\text { same }\end{array}$ & $\begin{array}{c}\text { Change } \\
\text { up }\end{array}$ \\
\hline Age at migration (min : $\max )$ & 9.8 & 4.4 & -14.3 \\
\hline Born in Australia (No : Yes) & 0.9 & 5.2 & -6.1 \\
\hline \multicolumn{4}{|l|}{ Previously taken post-school courses. At least one of... } \\
\hline Company based vocational course (No: Yes) & -1.2 & -2.1 & 3.4 \\
\hline Trade qualification (No: Yes) & -0.7 & -2.0 & 2.7 \\
\hline Post-trade qualifications (No : Yes) & -5.9 & 6.3 & -0.4 \\
\hline Traineeship (No : Yes) & 6.0 & -1.6 & -4.4 \\
\hline Undergraduate diploma (No: Yes) & -6.8 & 6.1 & 0.8 \\
\hline Year of job change (1970: 1994) & 10.4 & -17.5 & 7.1 \\
\hline
\end{tabular}

\section{ATTITUDES TOWARD TRAINING}

To complement this objective data on actual training and the effects on career changes, the survey also sought men's views about their attitudes towards further training. A series of 13 questions asked about first, whether they felt they needed additional training ${ }^{4}$, secondly, whether they were willing to undertake further training ${ }^{5}$ and thirdly, whether they believed their employers would support such training. ${ }^{6}$ Questions required a five-point Likert scale response with the anchors $1=$ strongly agree and $5=$ strongly disagree. This perceptual measure permits comparisons across different individuals and is easy to collect because it places fewer burdens on respondents than administrative or factual entries. However, it contains a subjective element and thus an undefined error and it would be unwise to over interpret the findings.

\footnotetext{
${ }^{4}$ This mainly include response to the questions: 'I feel I need additional training but I'm unsure how to get it', 'I feel my skills are good enough for my job', 'I feel my skills are good enough for my job', 'More training is required if I want a promotion', 'I do not feel that further training would allow me to earn more', 'I need to have my existing skills formally recognised rather than have further training', 'I do not feel that further training would be formally recognised by employers'.

5 'I would find formal training too difficult', 'I haven't worked in the semi-skilled or skilled area for many years and would be unlikely to ever want further training for this sort of work', 'I would be prepared to do further training during my own non-work time', 'I would be prepared to pay for the TAFE or college fees if I did more training ', 'I have undertaken quite a few training courses over my career'.

6 'My employer would not give me time off work to get further training', 'My employer would not pay for the TAFE or college fees'.
} 
These attitudinal variables are constructed as a summary of several questions rather than a single question. Questions were grouped by first, selecting a priori items it was believed represented aspects of the particular attitude. We then undertook factor analysis and rejected those items with factor loadings below 0.25 and derived measures based on the average of the five-point Likert scale of the remaining items. ${ }^{7}$ The main problems with using factor variables as explanators is first, it is difficult to interpret the values the variable takes and secondly, there is potentially missing data present in such constructed factor variables. To overcome both these problems, a summated scale is constructed as the average score on questions answered that corresponded to the factor.

The average score for each of these summated scores by career cluster and number of formal training courses undertaken are presented in Table 4. The lower the score, the more that respondents within the group agreed with the sentiments of the statement at the top of the column.

Men who had begun their career in the trade and had either left the trade to less or unrelated work or were still in the trade at the age of 40 were statistically no more likely than average to feel they needed additional training and were less likely to believe that their employer would support them. Men who had moved from a trade job to a higher supervisory or managerial job were significantly more willing to undertake further training.

If we classified the same sample of men by their training histories a clearer pattern emerges. Working men who had previously done more than one course were most likely to want more training and believe they needed more training. However they were less likely to believe that their employers would support additional training. These results suggest one of two things. Either those men working in jobs and careers that have required higher levels of formal skill acquisition also are likely to further require further formal training program, or, alternatively, there are men with this predisposition for formal training, for individual and personal background reasons, and men who

\footnotetext{
${ }^{7}$ Where appropriate, the 1 to 5 scales were reversed to order items in a consistent direction.
} 
have this predisposition will have both a history of formal education and training and a continuing positive attitude towards more formal courses. Reality may lie between these two alternatives.

Table 4: Summated scores of attitudes towards further training by career cluster $^{(a)}$

\begin{tabular}{|c|c|c|c|c|}
\hline & Cluster & $\begin{array}{l}\text { I need } \\
\text { additional } \\
\text { training }\end{array}$ & $\begin{array}{l}\text { I am willing to } \\
\text { undertake } \\
\text { additional } \\
\text { training }\end{array}$ & $\begin{array}{l}\text { My employer } \\
\text { would support } \\
\text { additional } \\
\text { training }\end{array}$ \\
\hline & Career cluster & & & \\
\hline 1 & Remain higher & 3.53 & 3.02 & 2.79 \\
\hline 2 & Clerical/sales to mixed & $3.20 \dagger$ & 2.87 & 2.86 \\
\hline 3 & Trade to lower & 3.38 & 2.89 & $3.06 \dagger$ \\
\hline 4 & Trade to higher & 3.39 & $2.59^{*}$ & 2.80 \\
\hline 5 & Remain trade & 3.45 & 2.84 & 2.88 \\
\hline \multirow[t]{5}{*}{6} & Unskilled to mixed & 3.37 & $3.05^{*}$ & 2.85 \\
\hline & Training history & & & \\
\hline & $\begin{array}{l}\text { No formal training } \\
\text { courses }\end{array}$ & 3.52 & $3.10^{*}$ & $2.65^{*}$ \\
\hline & $\begin{array}{l}\text { One formal training } \\
\text { course }\end{array}$ & $3.53 * *$ & $3.03 * *$ & $2.97 \dagger$ \\
\hline & $\begin{array}{l}\text { More than one formal } \\
\text { training course }\end{array}$ & $3.25^{* *}$ & $2.67 * *$ & 2.86 \\
\hline Total & & 3.39 & 2.85 & 2.87 \\
\hline $\mathrm{N}$ & & 455 & 461 & 414 \\
\hline
\end{tabular}

\section{CONCLUSION}

Persistent patterns in tradesmen's career paths provide some evidence that there is more than one stream of trade work. The first stream is trade jobs that require lower level academic skills and possibly a smaller selection of vocational skills. These jobs have a relatively flat skill acquisition path, so that skills do not continue to accumulate beyond a short initial period. Accordingly, ageearnings profiles are flat and employers did not bid up wages in order to retain dissatisfied workers. Early school leavers who did not take vocational courses at school had the greatest chance of beginning their working careers in unskilled work. Additionally, tradesmen with limited schooling and few vocational and post-school training courses had the greatest chance of leaving trade work for less skilled work before the age of 40 . Both types of people could be said to belong to this 
lowest stream. Men in this lowest stream are also least likely to believe they need more training or to indicate they want more training than other tradesmen.

On the other hand, the highest trade stream involves career paths that pass through trade work and continue through to higher technical, supervisory and managerial work. Completing the final year of schooling, undertaking vocational training while at school, undertaking a trade qualification, diploma or degree were all significantly associated with belonging to this highest stream. These workers appear to be most disposed towards more training.

In the middle remain men who begin and remain in the trade throughout most of their working lives although our data indicates that, over time, the lowest and highest streams are becoming more common. This middle stream appears to demand middle range level academic and vocational skills.

While more schooling and formal vocational courses (both qualification courses and short ad hoc courses) are associated with progressing along skill career paths, causality is more difficult to establish. The innate personal characteristics of the men, such as focus, diligence, determination and motivation, may make them more desirable workers for skilled positions as well as making them more able and interested in formal learning. Alternatively, fortune may place some men in a position where they receive more opportunity for formal and informal skill acquisition, and these experiences finally culminate in the more progressive career paths. It would be unlikely that either alternative is completely wrong or right, but we are unable to know from our data set where the true situation lies on this spectrum.

This view of the trade labour markets has implications for the training system that serves it. A single middle range form of vocational training, such as the three to four year apprenticeship, may be too much formal training for the lowest stream of trade worker and too little formal training for the person destined for the highest stream. One and two year apprenticeships may serve the needs to the lowest stream, however, currently there are few AQF I and II courses in the old 'declared' 
trades. On the other hand, higher advanced certificate and diploma courses may be a more efficient pre-employment training vehicle for the highest stream. ${ }^{8}$ For alternative forms of training to be fully efficient, graduates should be licensed where appropriate.

\footnotetext{
${ }^{8}$ It may be more efficient to have significant up-front training rather than to supplement career of people in the highest stream with ad hoc courses over their working lives.
} 


\section{APPENDIX A}

The intention was to survey men who had spent some time in the careers working in the trade and related occupations. This included unskilled and semi-skilled blue collar work as well as higher technical, supervisory, managerial and professional work. The survey population was initially approached by telephone over the period June 2000 to October 2001 and asked first, whether they had spend time in their careers working in the trade occupations - as defined above- and secondly, if they had, whether they would agree to participate in a postal survey on their work experiences. The telephone survey is a regular monthly survey undertaken by the Melbourne Institute has an approximate positive response rate from a random draw of telephone numbers of one in six. It is stratified by State but excludes the Northern Territory. The age of the respondent is randomly selected from households.

Sixty-four per cent of people approached by telephone, who filled the previous trade work criteria, agreed to undertake the postal survey. Characteristics of this population by whether they agreed to participate are given below in Tables A 1 to A 3. These show that there is little bias in the selection of people agreeing to participate by age group (Table A 1), broad occupation (Table A 2) and annual household income (Table A 3). However, men whose household incomes was in the $\$ 31 \mathrm{~K}$ to $\$ 40 \mathrm{k}$ bracket were slightly more likely and those who refused to give their house hold incomes were slightly less inclined to participate in the survey.

Of the 1937 men who agree to complete the postal survey, 1125 returned a completed questionnaire (58.1 per cent).

Table A 1: Percentage agreeing to undertake postal survey, by age group

\begin{tabular}{|c|c|c|c|c|c|}
\hline & TOTAL & $18-24$ years & $25-34$ years & $35-49$ years & $50+$ years \\
\hline Yes & 64 & 60 & 65 & 66 & 60 \\
\hline No & 35 & 39 & 33 & 33 & 39 \\
\hline Don't know & 1 & 2 & 1 & 1 & 1 \\
\hline Total & 100 & 100 & 100 & 100 & 100 \\
\hline
\end{tabular}


Table A 2: Percentage agreeing to undertake postal survey, by occupation group

\begin{tabular}{lrrrrr}
\hline & $\begin{array}{c}\text { Manager/ } \\
\text { Prof. }\end{array}$ & $\begin{array}{c}\text { Clerks/Sal } \\
\text { es }\end{array}$ & $\begin{array}{c}\text { Para } \\
\text { persons }\end{array}$ & $\begin{array}{c}\text { Prof./Trade } \\
\text { s }\end{array}$ & $\begin{array}{c}\text { Plant/Mach Retired/Un } \\
\text { ine }\end{array}$ \\
Op./Labour & $\begin{array}{c}\text { Remp./home } \\
\text { emuties }\end{array}$ \\
\hline Yes & 66 & 66 & 63 & 66 & 60 \\
No & 33 & 32 & 36 & 33 & 39 \\
Don't know & 1 & 2 & 1 & 1 & 1 \\
Total & 100 & 100 & 100 & 100 & 100 \\
\hline
\end{tabular}

Table A 3: Percentage agreeing to undertake postal survey, by household income

\begin{tabular}{lrrrrrrr}
\hline & Up to & $\mathbf{\$ 2 1 K}-$ & $\mathbf{\$ 3 1 K}-$ & $\mathbf{\$ 4 1 K}-$ & $\mathbf{\$ 5 1 K}-$ & & \\
& \$20K & $\mathbf{\$ 3 0 K}$ & $\mathbf{\$ 4 0 K}$ & $\mathbf{\$ 5 0 K}$ & $\mathbf{\$ 7 0 K}$ & $\mathbf{\$ 7 1 K}+$ & Ref \\
\hline Yes & 62 & 73 & 75 & 66 & 68 & 67 & 53 \\
No & 37 & 25 & 25 & 34 & 30 & 33 & 46 \\
Don't know & 1 & 1 & 0 & & 1 & 1 & 2 \\
Total & 100 & 100 & 100 & 100 & 100 & 100 & 100 \\
\hline
\end{tabular}




\section{Appendix B}

Table B 1: Multinomial logit estimates of factors affecting which career paths workers have followed

\begin{tabular}{|c|c|c|c|c|c|c|c|c|c|c|}
\hline & \multicolumn{2}{|c|}{ Higher skilled } & \multicolumn{2}{|c|}{ 'Trade to lower' } & \multicolumn{2}{|c|}{ 'Trade to higher' } & \multicolumn{2}{|c|}{ 'Remain trade' } & \multicolumn{2}{|c|}{$\begin{array}{c}\text { 'Unskilled to trade \& } \\
\text { higher' }\end{array}$} \\
\hline & Coefficient & z-statistic & Coefficient & z-statistic & Coefficient & z-statistic & Coefficient & z-statistic & Coefficient & z-statistic \\
\hline Age & 0.050 & 5.820 & -0.048 & -4.300 & 0.011 & 1.320 & 0.020 & 2.450 & -0.009 & -1.160 \\
\hline Level of schooling & 0.366 & 4.320 & -0.177 & -1.870 & -0.025 & -0.310 & -0.277 & -3.620 & -0.255 & -3.640 \\
\hline Vocational education course at school? & 0.073 & 0.400 & 0.260 & 1.310 & 0.829 & 4.880 & 0.421 & 2.520 & -0.174 & -1.050 \\
\hline \multicolumn{11}{|l|}{ Enrolled in training or education } \\
\hline Basic vocational course at TAFE & 0.298 & 1.370 & -0.357 & -1.360 & 0.314 & 1.500 & -0.138 & -0.640 & -0.481 & -2.300 \\
\hline Company based vocational course & 0.189 & 0.700 & 0.163 & 0.530 & 0.380 & 1.490 & -1.106 & -3.360 & 0.226 & 0.910 \\
\hline Trade qualification & 0.274 & 1.310 & 2.673 & 11.340 & 2.832 & 13.880 & 2.028 & 11.310 & -0.081 & -0.450 \\
\hline Post-trade qualifications & 0.310 & 1.100 & -0.149 & -0.510 & 0.567 & 2.290 & -0.410 & -1.520 & -0.635 & -2.040 \\
\hline Traineeship & 0.406 & 1.020 & 0.690 & 1.620 & -0.492 & -1.000 & 0.090 & 0.220 & -0.944 & -2.110 \\
\hline Undergraduate diploma & 0.836 & 3.170 & -1.057 & -2.030 & 0.747 & 2.620 & -0.842 & -2.180 & -1.973 & -3.950 \\
\hline Degree & 0.960 & 3.950 & -0.058 & -0.140 & 0.520 & 1.710 & -43.968 & 0.000 & -0.236 & -0.870 \\
\hline Basic literacy/numeracy & 22.827 & . & 24.979 & 22.760 & 23.801 & 21.090 & 23.037 & 19.480 & -23.017 & . \\
\hline Constant & -5.005 & -7.260 & 1.291 & 1.650 & -2.428 & -3.660 & -0.353 & -0.580 & 2.355 & 4.130 \\
\hline
\end{tabular}

Base category: 'Clerical to trade \& higher' 
Table B 2: Variable definitions and descriptive statistics ${ }^{a}$

\begin{tabular}{|c|c|c|c|}
\hline Variable & Description & Mean $^{b}$ & Standard deviation \\
\hline Respondents need more training & $\begin{array}{l}\text { A } 5 \text {-item, } 5 \text { point scale measuring the extent to } \\
\text { which respondent felt they needed more } \\
\text { training to do their job }(\alpha=0.52)\end{array}$ & 3.32 & 0.97 \\
\hline $\begin{array}{l}\text { Respondents willing to do more } \\
\text { training }\end{array}$ & $\begin{array}{l}\text { A } 3 \text {-item, } 5 \text { point scale measuring the extent to } \\
\text { which respondent felt they needed more } \\
\text { training to do their job }(\alpha=0.55)\end{array}$ & 2.79 & 1.27 \\
\hline $\begin{array}{l}\text { Respondents' employers support } \\
\text { training }\end{array}$ & $\begin{array}{l}\text { A 3-item, } 5 \text { point scale measuring the extent to } \\
\text { which respondents felt their employer would } \\
\text { support more training }(\alpha=0.61)\end{array}$ & 2.95 & 1.00 \\
\hline
\end{tabular}

a. Only items with factor loadings with absolute values greater than 0.25 are included in the variable measure.

Source: Melbourne Institute Tradesmen Survey 2001

b. $1=$ strongly agree, $3=$ neutral, $5=$ strongly disagree

Table B 2: Multinomial estimates of factors associated with job changes from one major skill group to another at each 5-year interval to the age of $\mathbf{4 0}$

\begin{tabular}{lcccr}
\hline & \multicolumn{2}{c}{ Move down } & \multicolumn{2}{c}{ Move up } \\
\hline Age at migration (=0 if born in Aust) & Coefficient & Z-statistic & Coefficient & Z-statistic \\
Born in Australia $(0,1)$ & 0.009 & 1.200 & -0.023 & -2.970 \\
Enrolled in training or education (0,1) & 0.010 & 0.050 & -0.408 & -2.280 \\
$\quad$ Basic vocational course at TAFE & & & & 0.980 \\
$\quad$ Company based vocational course & 0.123 & 0.880 & 0.116 & 1.490 \\
$\quad$ Trade qualification & -0.087 & -0.450 & 0.219 & 1.890 \\
$\quad$ Post-trade qualifications & -0.033 & -0.290 & 0.192 & -0.790 \\
$\quad$ Traineeship & -0.757 & -3.540 & -0.111 & -1.030 \\
$\quad$ Undergraduate diploma & 0.465 & 1.980 & -0.285 & -0.180 \\
$\quad$ Degree & -0.963 & -2.890 & -0.034 & -0.060 \\
Basic literacy/numeracy & -0.212 & -0.960 & -0.010 & 1.380 \\
Year of job change & 0.943 & 2.040 & 0.632 & -0.410 \\
Post-1988 (1 to 13) & -0.014 & -2.180 & -0.002 & -0.050 \\
Constant & 0.013 & 0.630 & -0.001 & 0.310 \\
\hline N=3352 & 26.449 & 2.050 & 3.762 &
\end{tabular}




\section{References}

Booth, A. (1991) 'Job related formal training: Who receives it and what is it worth?', Oxford Bulletin of Economics and Statistics, 53.

Green, F. (1993) 'The determinants of Training of Male and Female Employees in Great Britain', Oxford Bulletin of Economics and Statistics, 55, 103-22.

Greenhalgh, C., Longland, M. and Bosworth, D. (2000) Technological Activity and Employment in a Panel of UK Firms, Milan, Eurpoean Association of Labour Economists and the American Society of Labour Economists Joint Conference.

Greenhalgh, C. and Mavrotas, G. (1994) ' The Role of Career Aspirations and Financial Constraints in Individual Access to Vocational Training', Oxford Economic Papers, 46, 579-604.

Greenhalgh, C. and Mavrotas, G. (1996) 'Job Training, New technology and Labour Turnover', British Journal of Industrial Relations, 34.

Greenhalgh, C. and Stewart, M. (1987) 'The Effects and Determinants of Training', Oxford Bulletin of Economics and Statistics, 49.

Nickell, S. (1982) 'The determinants of occupational success in Britain', Review of Economic Studies, XLIX, 43-53.

Thomas, C. (1988a) Separation from Professions and Para-Professions, AGPS, Canberra.

Thomas, C. (1988b) Separation from the Trades, AGPS, Canberra.

VandenHeuvel, A. and Wooden, M. (1996) The Experience of Immigrants in Work-related Training, AGPS, Canberra. 
Webster, E., Dockery, M., Bainger, T. and Kelly, R. (2001) Training for the skilled trades in Australia: 1980 to 2000., National Centre for Vocational Education Research, Leabrook, South Australia.

Webster, E. M. (1983) Economic aspects of apprenticeship with special reference to seven Victorian trades. 1950 - 1982., In Economics Department, Monash University, Melbourne.

Webster, E. M. (1999) 'Occupational profiles of men since 1947', Australian Journal of Labour Economics, 3, 2.

Webster, E. M. (2001) 'The Rise of Intangible Capital and Labour Market Segmentation', Australian Bulletin of Labour, 27, 258-71. 


\section{University Library}

\section{- M M N E R VA A gateway to Melbourne's research publications}

Minerva Access is the Institutional Repository of The University of Melbourne

Author/s:

Webster, E;Jarvis, $\mathrm{K}$

Title:

The Occupational Career Paths of Australian Tradesmen

Date:

2003-12

Citation:

Webster, E. \& Jarvis, K. (2003). The Occupational Career Paths of Australian Tradesmen. Labour \&amp; Industry: a journal of the social and economic relations of work, 14 (2), pp.61-81. https://doi.org/10.1080/10301763.2003.10669288.

Persistent Link:

http://hdl.handle.net/11343/33744 